\title{
Management Premises and Barriers in the Metal Industry in Poland in the Context of Innovative Activity
}

\author{
Marta Daroń ${ }^{1, * \mathbb{D}}$ and Monika Górska ${ }^{2}$ \\ 1 Faculty of Management, Czestochowa University of Technology, Armii Krajowej 19B, \\ 42-201 Częstochowa, Poland \\ 2 Faculty of Production Engineering and Materials Technology, Czestochowa University of Technology, \\ Armii Krajowej 19, 42-201 Częstochowa, Poland; monika.gorska77@wp.pl \\ * Correspondence: marta.daron@wz.pcz.pl; Tel.: +48-34-325-08-65
}

Received: 29 October 2019; Accepted: 25 November 2019; Published: 28 November 2019

\begin{abstract}
The metal industry is an important part of industrialized economies. It is not possible to imagine the development of such sectors as construction, automotive, or household appliance production without products of the metal sector. Moreover, metals are renewable raw materials, which is especially important for sustainable development. The main objective of the paper is to present management trends in metal market enterprises in Poland in the context of innovative activities. The paper characterizes this sector, presenting its importance for the Polish economy, and analyzes innovative activities of enterprises producing metals and metal products. To this end, domestic and international statistics were gathered and presented, supplemented with questionnaire surveys of a group of 112 enterprises from this sector. The presented results are broken down into small, medium-sized, and big enterprises, indicating differences in premises guiding enterprises when making managerial decisions in the field of innovation. Also, barriers to be overcome by metal sector enterprises differing in employment size are presented. The paper proves, e.g., that for all groups of surveyed enterprises, the process innovations are the most important, while product innovations are less important for small enterprises because this group of companies mostly manufactures very simple basic metal products.
\end{abstract}

Keywords: process; product; metal industry; innovation

\section{Introduction}

Today's market environment features a significant level of variability and the growing competition forces contemporary market entities to continuously improve and to introduce innovative solutions. Changes made in this field can be dictated by both internal and external factors [1-5]. From the organization's point of view, internal factors may result from a simple calculation of actions. Instead, external factors can result from regulations applicable to specific business activities [6] and environmental protection [7-10], level of competition, and the technology available on the market [11,12], as well as from prevailing trends, including corporate social responsibility and sustainable development [13]. It is necessary to emphasize that each factor resulting in the necessity for change, meaning to some extent improvement in the given area of activity, affects individual economic operators with a different force [11]. The market and legal limitations differ for each sector, because they result from its specific nature. Because of that, a question arises: how do entities from a specific sector adapt to changes of a closer and more remote environment? Even more, the path chosen by these entities is an interesting issue - this results in another question: are the innovative activities of 
given sector entities heading in the same direction? In this paper, an attempt is made to study this issue in the area of the metal industry because it is an important part of industrialized economies and the metals' life cycle is repeatable. There is a cognitive gap in the scientific literature in the field of the metal industry [12]. It concerns the current results of the innovative activities of this industry sector. In addition, the research results presented by national and international statistics are not complete in terms of geographical regions, political division, and in the subject of the study. Therefore, in this study, an attempt is made to update and supplement the current state of knowledge about the innovative activities of metal sector enterprises in Poland. From the point of view of the research problem, it is particularly important to determine the factors relevant to this industry that affect innovation activities in a positive and negative way. The research methodology presented in the available statistics is the same for industrial enterprises, regardless of the industry in which they operate [14-16]. Therefore, any study that is aimed at supplementing or extending the existing research results of the metal processing sector is justified and helpful from the point of view of decision makers operating in this area, both at the national and global level.

The main objective of the paper is to investigate what factors influence the process of undertaking innovative activity and what problems must be faced by managers of metal market companies in Poland in this context. To this end, available domestic and international statistic reports for the sector are analyzed, which are supplemented with results of a questionnaire survey of a group of 112 enterprises producing metals and metal products. Scientific literature from the field of innovation [17-21] and guidelines provided in the Oslo Manual [14] were used at the designing of the questionnaire. Despite a sizeable group of surveyed enterprises, its share in the entire population is less than $0.25 \%$. However, the carried-out survey is an interesting material for further studies in the field of innovation in the metal sector.

The metal industry may be divided into: The production of steel and non-ferrous metals, that is, metallurgy, the distribution of steel and steel products, and metalworking. Metalworking may be divided into four subsets: (1) metalworking related to small enterprises, (2) metal structures, (3) boilers, metal containers and packaging, (4) metal products. The metal sector is strictly related to other fields of industry, like construction, machinery, automotive, or household appliance industries [22]. Hence, one cannot imagine economic growth without the metal industry, even more, it is frequently considered to be of strategic importance [23]. Non-precious metals, mainly steel, are the most popular raw materials used by the metal sector [24]. The steel production is dominated by the biggest economies of the world, including China, the European Union, and Japan [23]. At the same time, the fact that operations of metal industry enterprises have a negative environmental impact draws attention. Therefore, newer and newer legal regulations have originated, aimed at reducing greenhouses gases (GHG) emissions, heavy metals pollution, or amounts of discharged wastewater polluted mechanically, chemically, and biologically. The European Union is leading in that respect, as it already in 2007 adopted under The 7th Environment Action Program (EAP) new guidelines on environmental protection [25] and, three years later, the Directive of the European Parliament and of the Council of 24 November 2010 (Industrial Emissions Directive-IED) [26] imposed on manufacturing enterprises of the metal sector the necessity to obtain so-called integrated permits for the introduction of pollutants to the environment. All these changes cause necessity for metal sector enterprises to adapt to market requirements and thereby force the introduction of innovation in the field of manufactured products and carried-out processes. 


\section{Literature Review: Background-Innovative Activities}

The scientific literature comprises very many papers, the titles of which contain innovation term. For example, in the Science Direct database browser more than 521,000 results are displayed after entering the term "innovation" [27]. Moreover, it is possible to notice a growing trend of papers since 1996.

The term "innovation", according to the management dictionary, originates from a Latin word "innovatio", that is, renewal, and is a series of actions resulting in the creation of new or improved products, technological processes, or organizational systems [28]. Last century, Schumpeter indicated the importance of innovation [29], defining it as the creation of fundamental or radical changes that meant the transformation of new ideas and inventions into marketing products or processes [30,31]. P. Drucker considers innovation in a similar way-according to him, the innovation that is not applied on the market remains only a concept, an unrealized idea [31,32]. Many years ago, Freeman was also drawing attention to the importance of innovation [33], stating that the non-introduction of innovation is equivalent to an organization's death. Today, any successful, from an economic point of view, implementation of a new idea is considered innovation [34].

For the needs of this paper, we assumed that any activity of an enterprise aimed at the introduction of change (product, process, or other) contributing to the enterprise operation's improvement inside and outside and which is new to this enterprise, is an innovative activity.

Innovative activities may relate to many areas of the enterprise's activity. The most commonly used division is into four main categories: process, product, organizational, and marketing innovations [14]. It was noticed that the process of innovation development varies depending on the enterprise and its size, as well as the sector in which this entity operates [3]. The introduction of innovations depends on many factors, including strategic, operational, environmental, and social opportunities that work positively [35], but also those that impede their introduction, such as long investment cycles or high costs and potential loss of market share due to failures in the production process [36]. Especially in heavy industries, such as metallurgy, technology innovations are considered to be the most costly, risky, and time consuming [12]. Instead, referring to barriers, which are reported in the literature in the field of carrying out innovative activity, they may be combined most often into four groups: economic, related to the enterprise, legal, and other $[17,18,37]$. Progress in the digital transformation and the growing interconnections of market entities made under the Industry 4.0 concept also have an undeniable contribution to the development of innovation [35,38,39].

The scientific literature provides many reasons for innovation implementation [19,20,40,41], e.g., the willingness to develop a new product or cut costs, to increase the process effectiveness, or the necessity of adapting to regulations. The level of an enterprise's innovativeness, according to available papers $[37,42,43]$, is affected by such factors as cooperation with scientists and inventors, cooperation with scientific centers, employees' skills/involvement, enterprise reputation/image, manufacturing technology used, organization and management in the enterprise, and international and interregional cooperation links, that is, mostly broadly understood resources.

\section{Metal Sector Description in Poland}

In 2018, Polish enterprises of the metal sector produced more than $38,000,000$ tons of various basic metals [44] and this figure was $28 \%$ higher as compared with 2008. The value of the sold production of the metals and metal product producing industry in 2018 exceeded 165,110,000,000 PLN (Polish denomination: 1 euro $=4299$ PLN) [45]. This is $12 \%$ of the entire industrial sold production for that period [45]. Within 10 years, this figure went up by nearly 80\% from 92,053,000,000 PLN in 2008 . The market of metals and metal product production in Poland is substantially fragmented. This is proven by the number of economic operators, which in 2017 was 1289 entities producing metals and 39,512 entities manufacturing metal products [46], where the majority were small and medium-sized enterprises (more than 96\%) [46] working as subcontractors for various industrial sectors. The sector is attractive to foreign investors, despite the fragmentation. 
The metal sector comprises not only the production of non-precious metals, but also the production of precious metals, including silver and copper. Poland is one of the world powers in silver production. The most recent data made available by Statistics Poland (SP) refer to 2015-then, $1290 \mathrm{t}$ of pure silver were produced in Poland, which means that Poland's share in the global production of this metal was approx. $4.67 \%$ and a higher output was recorded only in seven states outside Europe [47]. The fact that the global demand for silver is increasing is promising. Industry is the most important field of this precious metal application. In 2017, almost a half of production was used in this economic sector. However, it is necessary to notice the fact that the industry used less silver than in the previous year [44]. Instead, the consumption in jewelry went up. Jewelers used nearly 7000 tons of silver. Silver is also used in tableware. In 2015, the production of such silver products was 2000 tons [48]. In 2017 also, the investments in silver increased [44].

Poland is also among the biggest copper producers worldwide [49]. According to Statistics Poland figures [47], in 2015 Poland ranked 19th among global producers of refined copper (574, 300tons), where its share in the global copper production was approx. $2.5 \%$ and among the EU countries only Germany produced more in that period. The share of copper sales value as against the total metals sales value in Poland was more than $18 \%$ in 2018 [44].

According to domestic statistics [46], more than 40,000 enterprises were operating on the Polish metal sector market in 2017. The private sector clearly dominated the public sector. The private sector comprised more than $99 \%$ of all enterprises in the metal industry.

The metal sector employs a significant number of people working in the industry. According to Statistics Poland figures, in 2017 this sector employed 335,800 persons [46], which gives a $12.78 \%$ total of employment in manufacturing. Figure 1 presents the employment structure broken down into enterprise sizes.

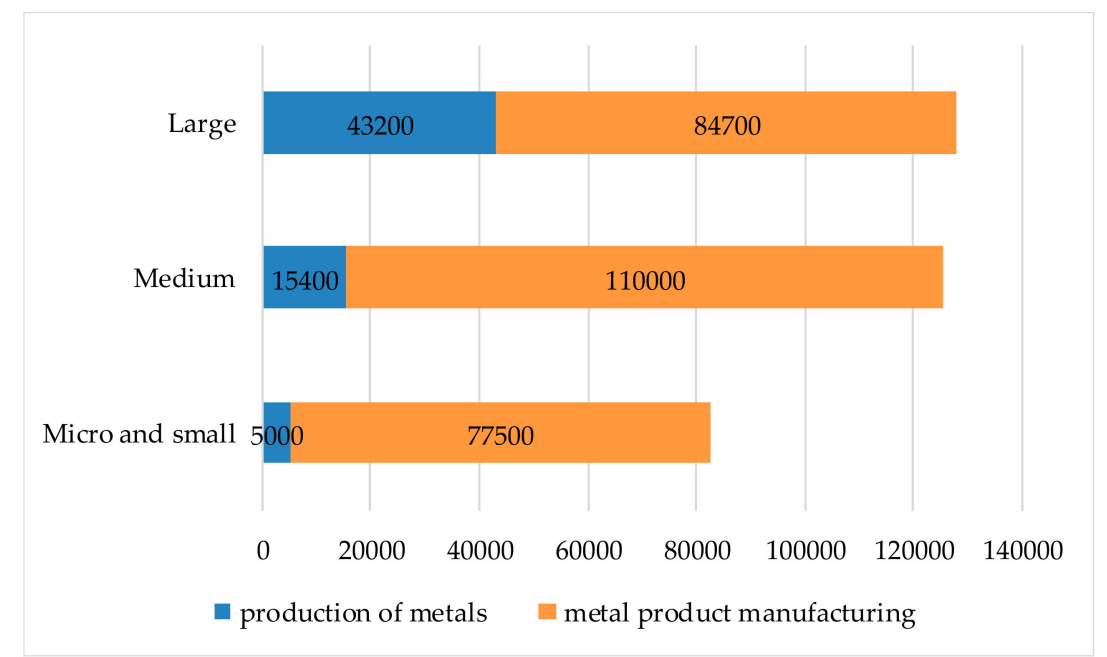

Figure 1. The employment in the metal sector in Poland in 2017. Source: Own study based on SP [46].

The metal sector, which belongs to the manufacturing industry, is an important element of the foreign trade. Table 1 presents Poland's trade in the field of the metal sector during the last 10 years. 
Table 1. Trade in the metal sector in the Polish economy.

\begin{tabular}{|c|c|c|c|c|c|c|}
\hline & $\begin{array}{l}\text { Export of Basic } \\
\text { Metals and } \\
\text { Fabricated Metal } \\
\text { Product (ths. } \\
\text { US Dollars) }\end{array}$ & $\begin{array}{l}\text { Share of Export } \\
\text { of Basic Metals }\end{array}$ & $\begin{array}{l}\text { Share of Export } \\
\text { of Fabricated } \\
\text { Metal Products }\end{array}$ & $\begin{array}{l}\text { Import of Basic } \\
\text { Metals and } \\
\text { Fabricated Metal } \\
\text { Product (ths. } \\
\text { US Dollars) }\end{array}$ & $\begin{array}{l}\text { Share of Import } \\
\text { of Basic Metals }\end{array}$ & $\begin{array}{c}\text { Share of Import } \\
\text { of Fabricated } \\
\text { Metal Products }\end{array}$ \\
\hline 2009 & $14,502,296$ & $50.90 \%$ & $47.49 \%$ & $14,160,576$ & $60.37 \%$ & $39.63 \%$ \\
\hline 2010 & $17,489,614$ & $56.76 \%$ & $43.24 \%$ & $17,975,508$ & $63.69 \%$ & $36.31 \%$ \\
\hline 2011 & $22,866,167$ & $58.44 \%$ & $41.56 \%$ & $22,874,774$ & $65.03 \%$ & $34.97 \%$ \\
\hline 2014 & $22,921,096$ & $52.03 \%$ & $47.97 \%$ & $22,378,250$ & $62.98 \%$ & $37.02 \%$ \\
\hline 2015 & $19,631,251$ & $51.00 \%$ & $49.00 \%$ & $19,451,158$ & $61.42 \%$ & $38.58 \%$ \\
\hline 2016 & $18,977,970$ & $47.27 \%$ & $52.73 \%$ & $19,623,560$ & $59.84 \%$ & $40.16 \%$ \\
\hline 2017 & $22,260,100$ & $48.66 \%$ & $51.34 \%$ & $23,445,322$ & $63.52 \%$ & $36.48 \%$ \\
\hline 2018 & $26,231,642$ & $46.22 \%$ & $53.78 \%$ & $29,105,660$ & $64.32 \%$ & $35.68 \%$ \\
\hline
\end{tabular}

Source: Own study based on the data from The Organisation for Economic Co-operation and Development OECD [50]. ths: thousands.

The presented data shows that the last year witnessed very favorable trends for the analyzed market. The levels before the economic crisis, which occurred in the global economy in 2008, were exceeded, which for the Polish metal sector resulted in a slump in 2009. The fact is that the share of metal product exports in this period grows and draws attention, while the advantage of basic metals is visible in imports.

The level of demand for steel is generated by the following sectors: road and rail infrastructure, the power sector, the construction industry, and the machinery industry [51]. The steel imports are a contemporary problem of the sector. In 2018, the share of imports in the steel used in Poland was two times higher than exports [50]. A part of steel was placed on the Polish market at dumping prices. Steel producers from the European Union postulated during protests the protection of the EU market against dumping from China, and also from Belarus. Also, the environmental aspect is an issue. Metallurgical plants in Europe are most modern and most efficient in terms of energy, while products manufactured in China are related to a high emission of carbon dioxide. Instead, Belarus adopted a strategy of giving the steel scrap a status of strategic raw material with regulated low prices [52]. Also, privatization was the issue that hit especially big metal sector enterprises in Poland after the economic reforms.

\section{Materials and Methods}

Statistics presented by domestic and global databases, i.e., Statistics Poland (SP), The Organisation for Economic Co-operation and Development (OECD), and Eurostat, were used to carry out the research part of this paper. The analysis of obtained data, presented in the context of the innovative activities of Polish metal sector enterprises, was supplemented with our own studies carried out in the form of a survey. The survey was conducted from May 2019 to July 2019. During the survey of factors deciding about innovative activities in this sector, 112 questionnaires were collected from enterprises differing in employment size and production type (metals and metal product production), and also in other parameters (Table 2).

Table 2. Description of surveyed enterprises.

\begin{tabular}{|c|c|c|c|c|c|c|c|}
\hline \multicolumn{2}{|c|}{ Level of Employment } & \multicolumn{2}{|l|}{ Profile of Business } & \multicolumn{2}{|c|}{$\begin{array}{c}\text { Period of Market } \\
\text { Operations }\end{array}$} & \multicolumn{2}{|c|}{ Area of Business } \\
\hline $10-49$ & 64 & Basic metals & 8 & Up to 5 years & 3 & Regional & 21 \\
\hline $50-249$ & 30 & $\begin{array}{l}\text { Metal products } \\
\text { manufacturing }\end{array}$ & 104 & $5-15$ years & 24 & Domestic & 68 \\
\hline 250 and more & 18 & $\begin{array}{l}\text { Manufacture of basic metals } \\
\text { and metal products }\end{array}$ & 0 & 15 and more years & 85 & International & 23 \\
\hline
\end{tabular}

Source: Own study. 
There were selected 200 subjects for the study. The selection of the survey sample was intentional, dictated by the willingness to gather as high as possible a number of properly filled questionnaires, so that it would be possible to identify factors deciding about carrying out innovative activities in the metal sector. Therefore, entities with registered offices in the area of Silesian Voivodeship, or in the area of neighboring voivodeships, were chosen for the survey. In most cases, the survey was conducted in person or by friends, which is the reason for the high percentage of completed surveys obtained. Respondents of direct questionnaires included both staff members managing the surveyed enterprises, due to their invaluable practical knowledge and in-depth knowledge of the company and sector, as well as employees knowing the issues of the undertaken survey, because only such people can provide a reliable answer. The processed survey was based on a questionnaire comprising closed questions, some with a possibility of expanding or supplementing certain answers. The questionnaire survey was partly related to a three-year period (2016-2018), because such a range of dates allowed us to verify the innovative activity, which is usually carried out in the form of a project lasting from a few to a dozen or so months. Moreover, the statistic reports used for the paper are also published in three-year periods (2014-2016 and 2015-2017), according to guidelines presented in the Oslo Manual. Therefore, the gathered data referring to the studied period of 2016-2018 may be a supplement to available statistics and allow the checking of trends in the studied area.

\section{Main Results}

Reports of Statistics Poland provide various domestic statistics carried out in the field of innovative activities of the metal sector. Some of them apply to entities employing 50 and more persons (Table 3), while others comprise the group of enterprises employing 10 and more persons (Table 4). However, they are connected by date ranges, for which statistics were prepared-these are three-year periods, i.e., 2014-2016 and 2015-2017, because such periods allow time to introduce innovation. The data presented in Table 3 show that in those two periods the share of innovative enterprises was higher in the group of bigger enterprises and this applies both to entities producing basic metals and to entities manufacturing metal products. The above specification was compared with the data made available in reports, prepared also by Statistics Poland [35,36], in which the methodology developed by Eurostat and OECD was used, presented in the Oslo Manual.

Table 3. Share of innovative enterprises with 50 and more employees in the periods of 2014-2016 and 2015-2017.

\begin{tabular}{|c|c|c|c|}
\hline \multirow{3}{*}{ Specification } & \multicolumn{3}{|c|}{$\begin{array}{l}\text { Enterprises that Introduced New or Significantly Improved } \\
\text { Products or Processes in \% of Total Enterprises }\end{array}$} \\
\hline & \multirow{2}{*}{ Total } & \multicolumn{2}{|c|}{ With the Following Number of Persons Employed } \\
\hline & & $50-249$ & 250 and more \\
\hline & \multicolumn{3}{|c|}{ 2014-2016 } \\
\hline Basic metals & 48.4 & 44.8 & 59.2 \\
\hline \multirow[t]{2}{*}{ Metal products manufacturing } & 35.9 & 33.2 & 53.4 \\
\hline & \multicolumn{3}{|c|}{ 2015-2017 } \\
\hline Basic metals & 45.3 & 37.7 & 64.7 \\
\hline Metal products manufacturing & 37.0 & 33.7 & 57.6 \\
\hline
\end{tabular}

Source: Own study based on SP [46,53]. 
Table 4. Share of innovative enterprises with 10 and more employees in the period of 2014-2017.

\begin{tabular}{cc}
\hline \multicolumn{2}{c}{ Innovative Enterprises in the Period of 2014-2016 [\%] } \\
\hline Basic metals & 24.5 \\
Metal products manufacturing & 15.9 \\
\hline Innovative Enterprises in the Period of 2015-2017 [\%] \\
\hline \multicolumn{2}{c}{ Basic metals } \\
Metal products manufacturing & 21.6 \\
\hline \multicolumn{2}{c}{ Source: Own study based on SP [15,16]. }
\end{tabular}

These studies comprise enterprises with a number of employees of 10 and more (Table 4).

When comparing the figures presented in Tables 3 and 4, it is possible to notice that the share of innovative enterprises is more than a half higher in both groups for the metal sector entities, comprising only medium-sized and big enterprises. The general trend was maintained. The share of innovative enterprises decreased in the period of 2015-2017 as against 2014-2016 in the metals production sector, while this share went up in the metal products manufacturing sector. A particularly high increase in the share of innovative enterprises for both sectors was recorded in the group of big enterprises.

Innovation-introducing enterprises may carry out their actions primarily in the field of products and processes. For comparison purposes, indices of enterprises introducing a given type of innovation in the group of big and medium-sized enterprises of the metal sector are also given here (Table 5), and in the group of small, medium-sized and big entities (Table 6), taking into account innovative activities also in the field of organization and marketing.

Table 5. Share of enterprises with 50 and more employees that introduced new or significantly improved products or processes in the period of 2014-2016 and 2015-2017.

\begin{tabular}{|c|c|c|}
\hline \multirow{3}{*}{ Specification } & \multicolumn{2}{|c|}{ Enterprises That Introduced } \\
\hline & $\begin{array}{l}\text { New or Significantly } \\
\text { Improved Products }\end{array}$ & $\begin{array}{l}\text { New or Significantly } \\
\text { Improved Processes }\end{array}$ \\
\hline & \multicolumn{2}{|c|}{ In $\%$ of Total Enterprises } \\
\hline & \multicolumn{2}{|c|}{$2014-2016$} \\
\hline Basic metals & 33.3 & 42.2 \\
\hline \multirow[t]{2}{*}{ Metal products manufacturing } & 23.9 & 31.0 \\
\hline & \multicolumn{2}{|c|}{ 2015-2017 } \\
\hline Basic metals & 35.4 & 40.3 \\
\hline Metal products manufacturing & 23.9 & 32.0 \\
\hline
\end{tabular}

When analyzing figures presented in Table 5, it is noticeable that in the group of medium-sized and big enterprises in both metal sectors in the period 2014-2016, as well as in 2015-2017, there were more enterprises introducing improved processes than products.

In the group of enterprises employing a minimum of 10 employees (Table 6), the share of innovative enterprises-for the analyzed periods and product and process innovations-was more than a half lower in the group of medium-sized and big enterprises (Table 5). In addition, in the metals production sector, in the next period a decline in all innovation types was recorded. 
Table 6. Metal sector enterprises with more than nine employees that were innovative in the years 2014-2017 by innovation types.

\begin{tabular}{cccccc}
\hline \multirow{2}{*}{ Specification } & Products & Processes & $\begin{array}{c}\text { Products and } \\
\text { Processes }\end{array}$ & $\begin{array}{c}\text { Organizational } \\
\text { Innovations }\end{array}$ & $\begin{array}{c}\text { Marketing } \\
\text { Innovation }\end{array}$ \\
\cline { 2 - 6 } & \multicolumn{5}{c}{ As the Share of Total Enterprises of a Given Economic Activity } \\
\cline { 2 - 6 } & \multicolumn{5}{c}{$\mathbf{2 0 1 4 - 2 0 1 6}$} \\
\hline Basic metals & 17.2 & 20.4 & 24.5 & 11.8 & 7.3 \\
\hline $\begin{array}{l}\text { Metal products } \\
\text { manufacturing }\end{array}$ & 11.0 & 14.3 & 15.9 & 10.9 \\
\hline
\end{tabular}

Source: Own study based on SP [15,16].

To check the importance of specific innovation type introduction for enterprise development, respondents were asked to mark in the questionnaire the answer yes or no. Results are presented in Figure 2.

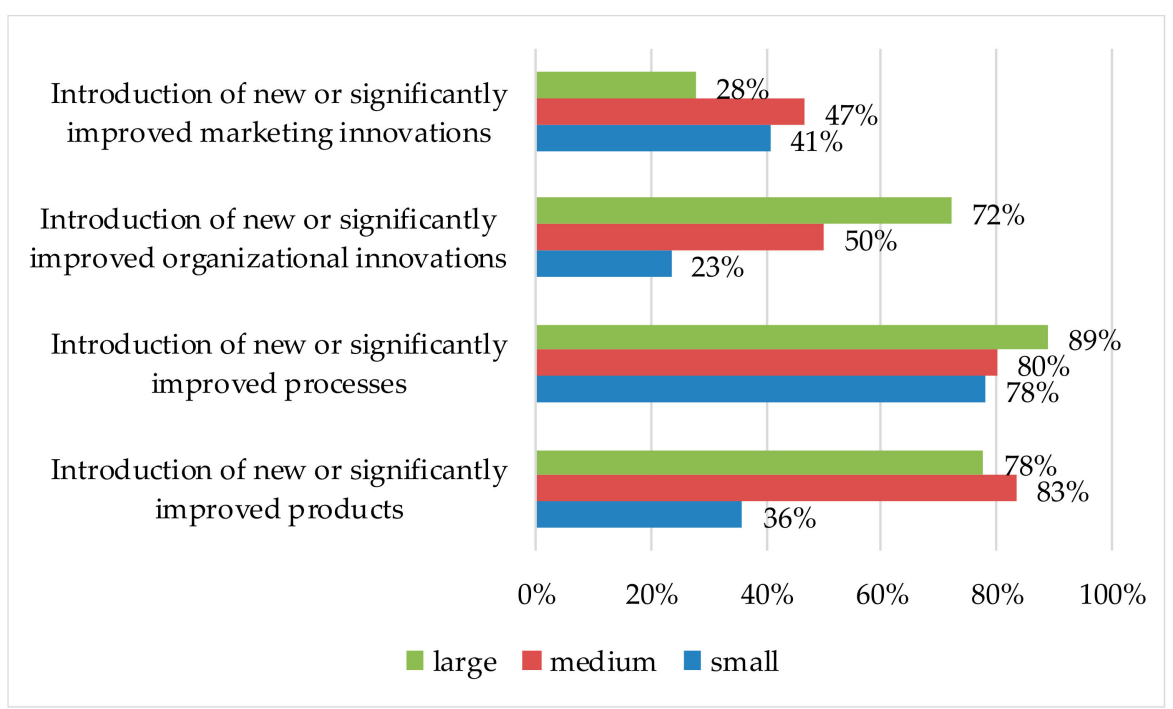

Figure 2. Innovation type and its importance for the development of metal sector enterprises.

The carried-out questionnaire survey shows (Figure 2) that a significant part of surveyed enterprises considers that the introduction of new or substantially improved processes and products is an important element contributing to their development. The smallest share of answers among small enterprises was recorded for organizational changes. However, in the field of marketing changes, shares of all enterprise group answers were relatively low, which is partly reflected in the data presented by Statistics Poland (Table 7) about expenditures on innovative activities (despite the fact that the survey comprised only medium-sized and big enterprises). 
Table 7. Expenditures on innovative activity [PLN million]. The data apply to enterprises in which the number of persons employed exceeds 49 .

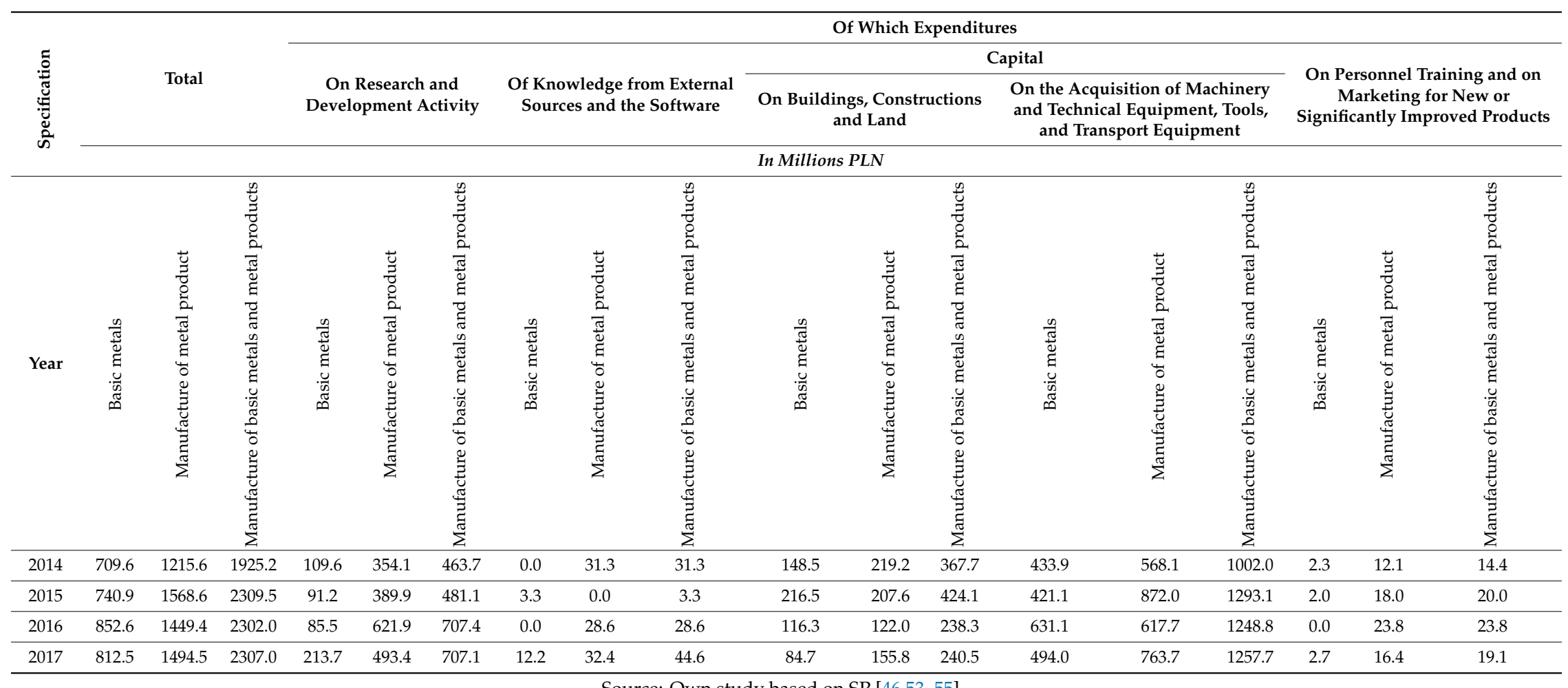

Source: Own study based on SP [46,53-55]. 
On the basis of the data presented in Table 7, it is possible to show that the expenditure on training and marketing was really low. Even more, the metals production sector in the period of 2014-2017 incurred the highest innovation expenditure in 2016 and most of it was assigned to machinery, technical equipment and tools, and means of transport-631,100,000 PLN. That was as much as $74 \%$ of the total expenditure on innovation in this group of producers. Also, for the group of enterprises manufacturing metal products, the innovation expenditures in the field of machinery, technical equipment and tools, and means of transport in the studied period feature the highest shares, but they peaked in 2015 . What is interesting is that a very big part of expenditure (621.9) was recorded in the group of metal products manufacturers in the field of research and development activity in 2016. In the period of 2014-2017, the studied enterprises incurred the lowest expenditure on the purchase of knowledge from external sources and software, and on staff training and marketing related to new or substantially improved products. It is worth noticing that the metal sector in the period of 2014-2017 financed the innovation almost entirely from its own sources (Table 8).

Table 8. Innovation financing sources in the years 2014-2017 in enterprises employing 50 and more persons.

\begin{tabular}{llcccc}
\hline \multirow{2}{*}{} & \multirow{2}{*}{ Specification } & \multicolumn{4}{c}{ Financing Sources in \% } \\
\cline { 3 - 6 } & & Own & From Abroad & Bank Credits & Others \\
\hline \multirow{2}{*}{2014} & Basic metals & 82.6 & 7.8 & 7.5 & 2.2 \\
& Metal products manufacturing & 68.4 & 11.6 & 11.1 & 8.9 \\
\hline \multirow{2}{*}{2015} & Basic metals & 83.7 & 6.5 & 4.9 & 4.9 \\
& Metal products manufacturing & 72.9 & 5.7 & 10.1 & 11.2 \\
\hline \multirow{2}{*}{2016} & Basic metals & 84.8 & 0.6 & 2.9 & 11.7 \\
& Metal products manufacturing & 83.1 & 2.1 & 6.4 & 8.4 \\
\hline \multirow{2}{*}{2017} & Basic metals & 85.7 & 4.4 & 6.5 & 3.4 \\
& Metal products manufacturing & 67.4 & 5.4 & 10.7 & 16.5 \\
\hline
\end{tabular}

Source: Own study based on SP [46,53-55].

The metals production section, apart from its own source of financing, acquired a part of its funds from abroad, due to the foreign capital involvement in those entities. Bank loans and other sources of innovation financing in most cases were on the level of a dozen or so percent, where a trend of the increasing interest of this sector's enterprises in other financing sources (the highest share for the entire sector-of around $20.1 \%$-was recorded in 2016) and a decreasing interest in loans were noticeable. At the same time the share of metal-producing entities, which obtained public financial support for innovation in the years 2014-2016, was 39\%, and in the group of metal products manufacturers, this share was $28 \%$ [15].

To determine the premises making the metal sector enterprises engage in innovative activity, such a question was asked in the questionnaire. Obtained results are presented in Figure 3.

When analyzing reasons for innovation implementation in a questionnaire survey, it is possible to notice that in the group of big enterprises, motifs related to product/process functioning improvement prevail ( $72 \%$ of surveyed enterprises). It is also justified by a continuous increase in the offered products' quality ( $83 \%$ answers). According to figures obtained from Statistics Poland, in the metal sector the biggest number of new or improved products was introduced by enterprises employing more than 250 employees. Such a situation occurred in all sectors. In the case of medium-sized enterprises, according to our own research, the reason most frequently indicated by enterprises was a willingness to cut the $\operatorname{cost}(70 \%)$ and a productivity increase $(60 \%)$, retaining a high quality of the offered products $(67 \%)$. The aspiration to increase profits is the main factor contributing to the fact that small enterprises are willing to introduce actions of an innovative nature. As many as $70 \%$ of the surveyed 64 enterprises indicated that factor. 


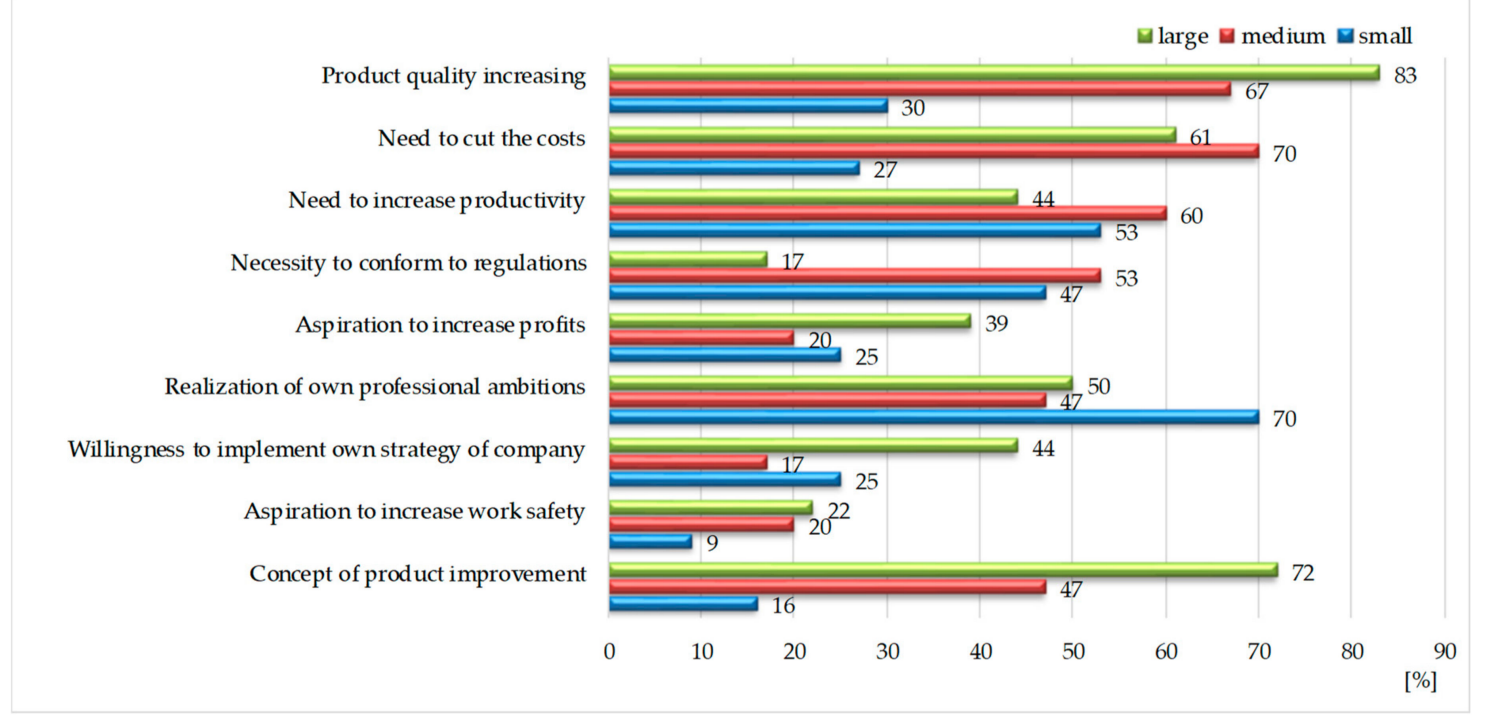

Figure 3. Reasons for innovation implementation in metal sector enterprises.

The next question comprised in the questionnaire was related to factors affecting decisions to start innovative activity by metal sector enterprises. In accordance with results obtained from the questionnaire survey, the factors with the greatest impact on innovative activity in big enterprises are employee skills in the field of research and development work (Figure 4). Big enterprises more frequently start cooperation with scientific centers and inventors because they are aware of those centers' role and knowledge in efforts to develop, design, and implement new solutions. These factors are equally important in raising external funds to carry out innovative work, which translated into the number of carried-out projects financed by such institutions as, say, The National Centre for Research and Development (NCR\&D). For example, the total number of projects carried out by this institution in 2017 was 9342 and was $22.4 \%$ higher than in 2016, when the number of carried-out projects was 7632. Also, the share of enterprises as beneficiaries having funds acquired from the NCR\&D increased from $25.20 \%$ in 2015 to $43 \%$ in 2017. Funds acquired in this way are used to improve all areas of enterprise activities. International cooperation links are a significant factor in this group of metal sector enterprises classified as big (100\% answers). In the studied case, all big entities belong to some international corporation with an established position on the market, strong brand, and broad manufacturing possibilities, which converted into the implementation of many solutions, both in the field of product design and processing, as well as distributing the manufactured products.

Based on the obtained survey results, it should be stated that in medium-sized enterprises the technical equipment is a factor that to a significant extent is responsible for the innovative activity $(83 \%)$ as well as the skills of employees ( $80 \%)$. The diffusion of the company's own solutions and products on the market is the factor that is also perceived by medium-sized enterprises (73\%). For those enterprises, marketing and sales are one of the key factors affecting the innovation of surveyed entities. Financial resources were the factor that was most frequently indicated by small enterprises (91\%). Such a high index obtained in the surveyed area results from the fact that small enterprises most frequently $(87 \%)$ finance innovative solutions from their own funds [39]. 


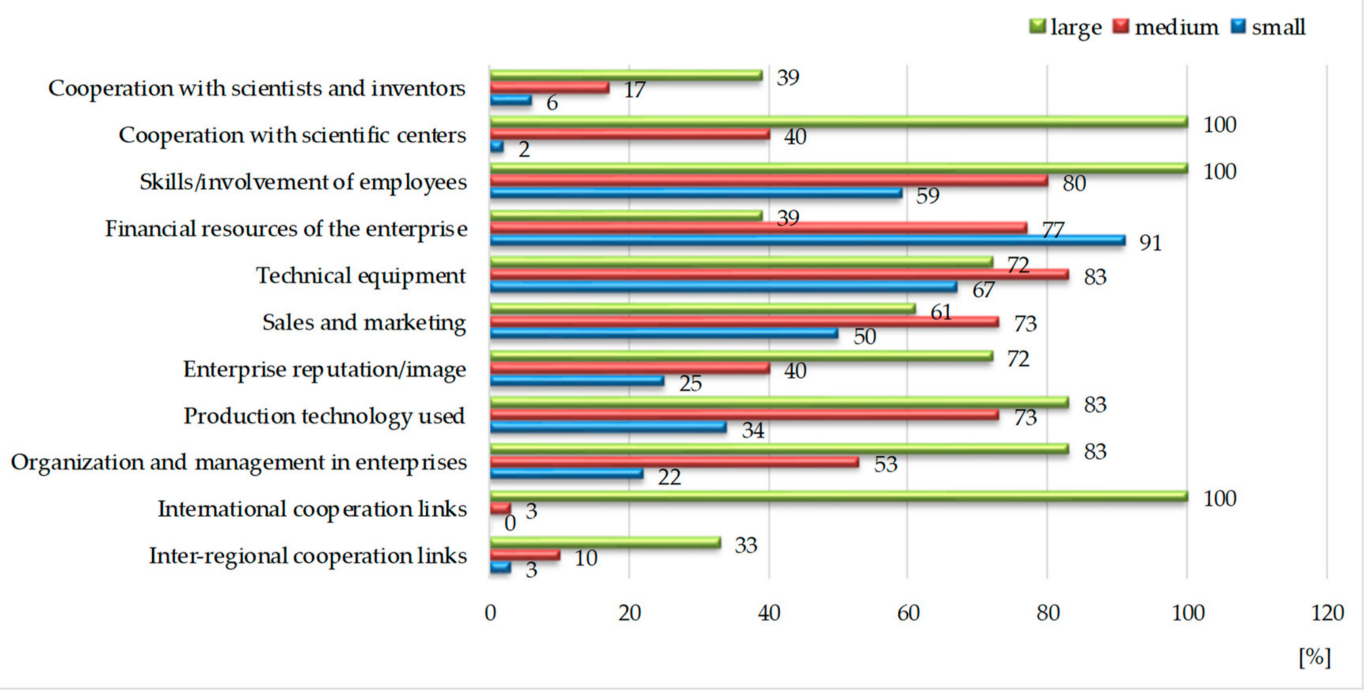

Figure 4. Factors having the biggest impact on innovative activity in surveyed enterprises.

In the context of the carried-out survey, the identification of basic barriers making the development and implementation of actions innovative in nature difficult is an important aspect. Figure 5 presents the results of the survey in this field.

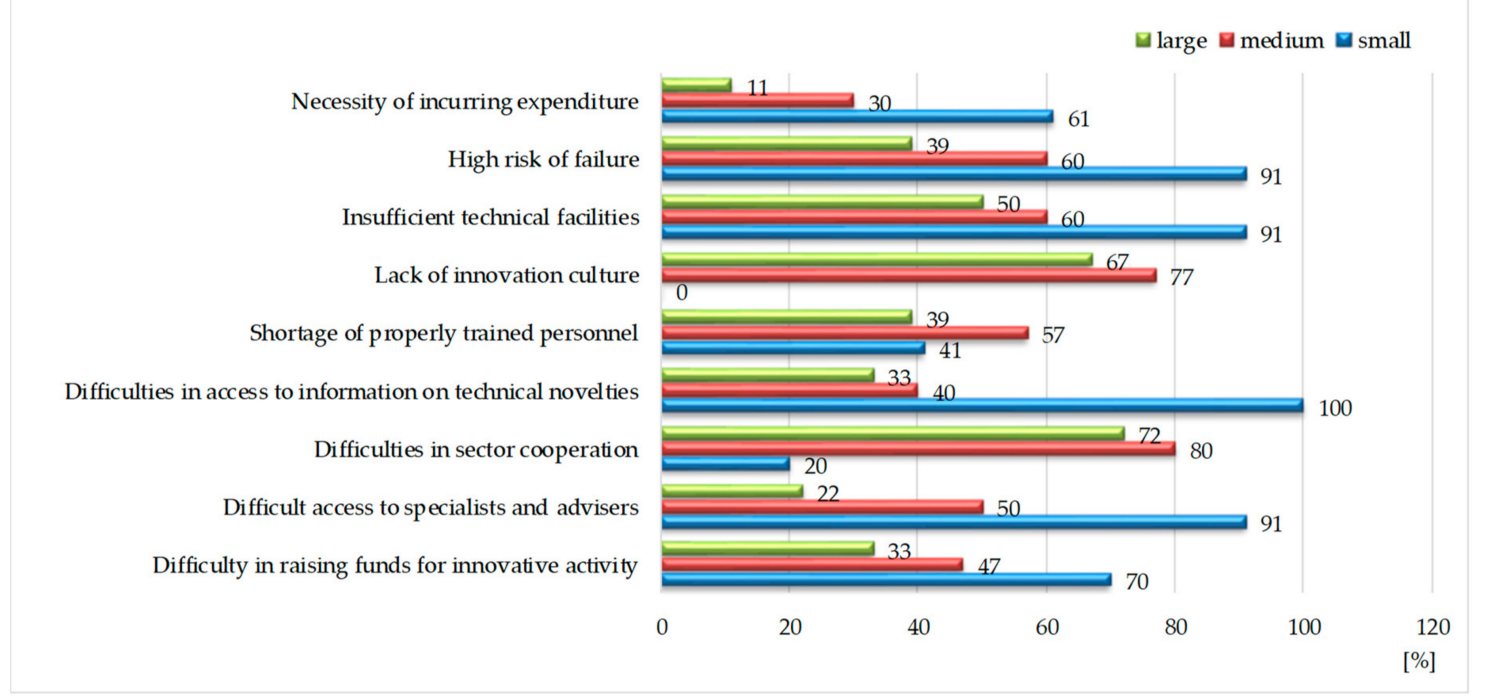

Figure 5. Barriers to innovative activity implementation in surveyed enterprises.

In the analyzed case-with respect to surveyed entities-the areas causing barriers to the introduction of innovative activities in small enterprises comprise difficulties in access to information on technical solutions (100\% of answers), which also has its grounds in the lack of access to specialists and advisers. A high risk of failure in undertaking innovative activities is also an important element with a high rate of answers ( $91 \%$ among small enterprises). That results from the lack of enterprises' interest in cooperation with scientific centers or in the case where such an attempt is even made, the obtained results of research may turn out to be too general to use them in production, which can result in resistance to the introduction of further change. Problems in this area should be sought in insufficient technical facilities, being the basis of developing and implementing actions of an innovative nature $(91 \%)$. 
In big and medium-sized enterprises, difficulties exist in the cooperation sector (70\% of answers), in particular in the access to information exchange between competitors, which is practically impossible due to the protection of the company's own patents. The lack of developed innovation culture was an important factor that was very frequently indicated as a barrier, mainly by big ( $70 \%$ of answers) and medium-sized ( $60 \%$ of answers) enterprises. Insufficient skills of employees (on any level), shortages in labor, and mental barriers are most frequently mentioned among barriers related to the staff. The last ones are related mainly to the change in hitherto thinking of the personnel and to the effects of a fear of change, which may turn out to be more difficult than financial barriers. A shortage of skilled employees with high competencies was also confirmed in surveys of Innovativeness of Polish Enterprises, in which $41 \%$ of respondents [56] considered this factor to be crucial in innovation implementation and improvement.

\section{Discussion}

The presented results show that the factors that positively influence the innovative activity of metal sector enterprises among large enterprises are: cooperation with scientific centers, skills/involvement of employees, and international cooperation links. By contrast, small and medium-sized enterprises rather point to the financial resources of the enterprise and technical equipment. Similarly, Wugan Cai and Guangpei Li [11] prove that factors such as the technological possibilities and organizational skills of the environment contribute to the development of innovation. Thus, we support the statement that strategic and operational, as well as environmental and social, opportunities are positive factors driving the implementation of innovation [35]. At the same time, the results presented in this study are more detailed because they not only specify these factors in the context of the metal production sector, but also contain a breakdown by enterprise size.

With regard to innovative activity barriers, Wesseling et al. [36] depict, among others, factors such as: long investment cycles that give little opportunity to change technologies, high costs, and potential loss of market share due to breakdowns in the production process, which in their opinion increases the perception of innovation risk. These results are partly confirmed in our study-more than $90 \%$ of small enterprises in the surveyed sector indicate such barriers as a high risk of failure and insufficient technical facilities.

Economic barriers in innovation implementation are mainly problems of innovation financing and the need for big financial expenditures on research and development activities. As Table 8 shows, innovation is financed mainly from the company's own sources, which is a big problem for small enterprises of the metal sector. A poor financial standing or the lack of possibility to find investors are the next economic factors that can be classified as innovation barriers. However, frequently, economic barriers are not only on the enterprise's side, but also on the state side, which does not create possibilities for them to overcome those internal barriers, e.g., through subsidies, co-financing, or loans at favorable interest rates. Those related to demand and competition on the market can also be considered economic barriers. They include primarily the organization's concern that innovative products will not find buyers, or that those innovation costs will be overestimated [57] as well as a fear of strong competition on the market [58].

Instead, legal barriers may include all regulations and legislation in force in a given country that in any way limit the possibility to implement innovation by enterprises. Usually, this is related to high costs, which an enterprise must incur to adapt to the governmental and EU regulations (at present, this is most often related to regulations applicable to environmental protection) [59]. While other barriers include all those factors that cannot be assigned to the previous three groups, e.g., the lack of scientific units interest in cooperation with enterprises or in the case where an attempt to cooperate was made, the obtained results might turn out too general to be applied in the production, can be included here. Indeed, difficulties in access to information on technical novelties and difficult access to specialists are the most frequently indicated barriers among small enterprises (Figure 5). 


\section{Conclusions}

The contemporary market sets more and more specialized requirements for enterprises, forcing greater competitiveness. Metal sector enterprises pursuing their own development and carrying out business are forced to look for and create innovative solutions in various areas of the business. This is confirmed by surveys, showing that the introduction of new or significantly improved processes, products, and organizational and marketing solutions is significant for many of the surveyed metal sector entities (Figure 2). Obviously, the process (a high share of answers in all employment size groups) and product (although a low share of answers in the group of small enterprises was recorded here, which may be explained by the fact that entities of this group manufacture mostly very simple and basic metal products) innovations are most important to respondents. In addition, the capability to create innovative solutions proves that the enterprise situation and its development possibilities are in a permanently changing environment. The presented statistics confirm that in the metal sector, the largest number of innovations was introduced by big and medium-sized enterprises (Table 3).

Based on a review of scientific as well as sectoral literature referring to the metal sector, nine reasons for implementing innovation were distinguished (Figure 3), of which the most frequently indicated by the surveyed entities were those related to the product and its quality improvement, and also to the economics of the operations (cutting costs, increasing profits). The presented studies confirm that just insufficient technical facilities are a barrier to innovative activity, which was indicated by $91 \%$ of small entities (Figure 5), and possession of appropriate financial resources is the most frequently indicated factor affecting the initiation of innovative activity in the group of small enterprises (Figure 4). Instead, intangible resources consist primarily of managerial and engineering skills, comprising skills of individuals and of groups, as well as their organization. It is also necessary to draw attention here to the group of small enterprises of the studied sector, for which access to information on technical novelties is a major issue (Figure 5).

Barriers related to enterprises include primarily problems with employees, an insufficient level of technology and engineering, or the organization's conviction of the lack of need to introduce new innovations due to those introduced previously. Insufficient skills of employees (Figure 5), shortages in labor, and mental barriers are most frequently mentioned among barriers related to the staff. The last ones are related mainly to the change in hitherto thinking of the personnel and to the effects of a fear of change, which may turn out to be more difficult than financial barriers [21].

In the presented study, there was made an attempt to specify factors that have a positive and negative impact on the innovative activity of metal production companies in Poland. Although the study had a regional constraint, a certain trend in this sector was presented, which could be revised in the future as a part of a wider study. Moreover, there are few studies in the available scientific literature on this economic sector in this field. Most often these are studies based on companies operating on Asian markets $[5,6,11,60,61]$, which makes comparison difficult because the European metal production sector has one of the most stringent legal regulation systems, e.g., in the field of environmental protection, while Asian markets do not have such restrictions. 
Author Contributions: The authors worked together on the research. Conceptualization, M.G.; methodology, M.G. and M.D.; literature and statistical research, M.D.; own research, M.G.; writing paper, M.G. and M.D.

Funding: This research received no external funding

Conflicts of Interest: The authors declare no conflict of interest.

\section{References}

1. Nguyen, H.L.; Larimo, J.; Wang, Y. Control, innovation and international joint venture performance: The moderating role of internal and external environments. Int. Bus. Rev. 2019, 28, 101591, ISSN 0969-5931. [CrossRef]

2. Vega-Jurado, J.; Gutiérrez-Gracia, A.; Fernández-de-Lucio, I.; Manjarrés-Henríquez, L. The effect of external and internal factors on firms' product innovation. Res. Policy 2008, 37, 616-632. [CrossRef]

3. Da Silva, F.M.; de Araujo Querido Oliveira, E.A.; de Moraes, M.B. Innovation development process in small and medium technology-based companies. Rai Rev. De Adm. E Inovação 2016, 13, 176-189, ISSN 1809-2039. [CrossRef]

4. Chesbrough, H. The logic of open innovation: Managing intellectual property. Calif. Manag. Rev. 2003, 45, 33-58. [CrossRef]

5. Shi, X.; Wu, Y. The effect of internal and external factors on innovative behaviour of Chinese manufacturing firms. China Econ. Rev. 2017, 46, S50-S64, ISSN 1043-951X. [CrossRef]

6. Tian, Y.; Wang, Y.; Xie, X.; Jiao, J.; Jiao, H. The impact of business-government relations on firms' innovation: Evidence from Chinese manufacturing industry. Technol. Forecast. Soc. Chang. 2019, 143, 1-8, ISSN 0040-1625. [CrossRef]

7. Tsai, W.-H.; Lan, S.-H.; Huang, C.-T. Activity-Based Standard Costing Product-Mix Decision in the Future Digital Era: Green Recycling Steel-Scrap Material for Steel Industry. Sustainability 2019, 11, 899. [CrossRef]

8. American Iron and Steel Institute. Steel Production, Recycling. Available online: http://www.steel.org/aboutaisi/industry-profile.aspx (accessed on 21 November 2019).

9. Pan, H.; Zhang, X.; Wu, J.; Zhang, Y.; Lin, L.; Yang, G.; Deng, S.; Li, L.; Yu, X.; Peng, H. Sustainability evaluation of a steel production system in China based on emergy. J. Clean. Prod. 2016, 112, 1498-1509. [CrossRef]

10. Goyal, S.; Routroy, S.; Shah, H. Measuring the environmental sustainability of supply chain for Indian steel industry: A graph theoretic approach. Bus. Process. Manag. J. 2018, 24, 517-536. [CrossRef]

11. Cai, W.; Li, G. The drivers of eco-innovation and its impact on performance: Evidence from China. J. Clean. Prod. 2018, 176, 110-118, ISSN 0959-6526. [CrossRef]

12. Karakaya, E.; Nuur, C.; Assbring, L. Potential transitions in the iron and steel industry in Sweden: Towards a hydrogen-based future? J. Clean. Prod. 2018, 195, 651-663. [CrossRef]

13. Behnam, S.; Cagliano, R.; Grijalvo, M. How should firms reconcile their open innovation capabilities for incorporating external actors in innovations aimed at sustainable development? J. Clean. Prod. 2018, 170, 950-965, ISSN 0959-6526. [CrossRef]

14. Oslo Manual 2018, Guidelines for Collecting, Reporting and Using Data on Innovation, 4th Edition. Available online: http://www.oecd-ilibrary.org/science-and-technology/oslo-manual2018_9789264304604-en?itemId=/content/publication/9789264304604-en\&mimeType=text/html\&_csp_ =f0a6f52d4530c0667c4c56b36905227f\&itemIGO=oecd\&itemContentType=book (accessed on 5 June 2019).

15. Innovative Activity of Enterprises In the years 2014-2016 Statistics, Poland, Statistical Office in Szczecin, Warszawa, Szczecin. 2017. Available online: http://stat.gov.pl/files/gfx/portalinformacyjny/ pl/defaultaktualnosci/5496/2/15/1/dzialalnosc_innowacyjna_przedsiebiorstw_w_latach_2014-2016.pdf (accessed on 18 September 2019). 
16. Innovative Activity of Enterprises in the Years 2015-2017 Statistics, Poland, Statistical Office in Szczecin, Warszawa, Szczecin. 2018. Available online: http://stat.gov.pl/files/gfx/portalinformacyjny/pl/ defaultaktualnosci/5496/2/16/1/dzialalnosc-innowacyjna-przedsiebiorstw-w-latach-2015-2017.pdf (accessed on 18 September 2019).

17. Chesbrough, H. Business Model Innovation: Opportunities and Barriers. Long Range Plan. 2010, 43, $354-363$. [CrossRef]

18. Lam, A. Organizational innovation. In The Oxford Handbook of Innovation; Fagerberg, J., Mowery, D., Nelson, R.R., Eds.; Oxford University Press: Oxford, UK, 2005.

19. Damijan, J.; Kostevc, C.; Rojec, M. Does innovation help the good or the poor performing firms? Econ. Lett. 2012, 115, 190-195. [CrossRef]

20. Hittmar, S.; Varmusa, M.; Lendela, V. Proposal of evaluation system for successful application of innovation strategy through a set of indicators. Procedia Econ. Financ. 2015, 26, 17-22. [CrossRef]

21. Knosala, R. (Ed.) Innowacje W Zarzadzaniu I Inżynierii Produkcji; Oficyna Wydawnicza Polskiego Towarzystwa Zarządzania Produkcja: Opole, Poland, 2013.

22. Metal Industry. Available online: http://ec.europa.eu/growth/sectors/raw-materials/industries/metals_en (accessed on 5 October 2019).

23. Globalization Patterns in EU Trade and Investment. Available online: http://ec.europa.eu/eurostat/ documents/3217494/8533590/KS-06-17-380-EN-N.pdf/8b3e000a-6d53-4089-aea3-4e33bdc0055c (accessed on 5 September 2019).

24. The EU Steel Industry. Available online: http://ec.europa.eu/growth/sectors/raw-materials/industries/metals/ steel_en (accessed on 5 September 2019).

25. European Commission. Analysis of Option to Move Beyond 20\% Greenhouse Gas Emission Reductions and Assessing the Risk of Carbon Leakage. 2010. Available online: http://eur-lex.europa.eu (accessed on 10 September 2019).

26. Directive 2010/75/Eu of the European Parliament and of the Council of 24 November 2010 on Industrial Emissions (Integrated Pollution Prevention and Control). Available online: http://eur-lex.europa.eu (accessed on 10 September 2019).

27. ScienceDirect.com. Available online: http://www.sciencedirect.com (accessed on 26 September 2019).

28. Encyklopedia Zarzadzania. Available online: http://mfiles.pl (accessed on 21 September 2019).

29. Schumpeter, J.A. The creative response in economic history. J. Econ. Hist. 1947, 7, 149-159. [CrossRef]

30. Schumpeter, J.A. Theory of Economic Development; Transaction Publishers: Piscataway, NJ, USA, $1983 ;$ p. 104.

31. Weryński, P. Research Methodology of Innovative Behaviour; Difin: Warszawa, Poland, 2015.

32. Drucker, P.F. Innovation and Entrepreneurship; Elsevier: Burlington, MA, USA, 1985.

33. Freeman, C. The Economics of Industrial Innovation; Penguin Books: London, UK, 1973.

34. Porter, M.E. The Competitive Advantage of Nations; The Macmillan Press Ltd.: London, UK, 1990.

35. Müller, J.M.; Kiel, D.; Voigt, K.-I. What Drives the Implementation of Industry 4.0? The Role of Opportunities and Challenges in the Context of Sustainability. Sustainability 2018, 10, 247. [CrossRef]

36. Wesseling, J.H.; Lechtenböhmer, S.; Åhman, M.; Nilsson, L.J.; Worrell, E.; Coenen, L. The transition of energy intensive processing industries towards deep decarbonization: Characteristics and implications for future research. Renew. Sustain. Energy Rev. 2017, 79, 1303-1313, ISSN 1364-0321. [CrossRef]

37. Weresa, M.A. Polityka Innowacyjna; PWN: Warszawa, Poland, 2014.

38. Ślusarczyk, B. Industry 4.0: Are we ready? Pol. J. Manag. Stud. 2018, 17, 232-248. [CrossRef]

39. Müller, J.M. Antecedents to Digital Platform Usage in Industry 4.0 by Established Manufacturers. Sustainability 2019, 11, 1121. [CrossRef]

40. Astebro, T.; Michaela, J.L. Predictors of the survival of innovations. J. Prod. Innov. Manag. 2005, 22, 322-335. [CrossRef] 
41. Porter, J.J.; Birdi, K. 22 reasons why collaborations fail: Lessons from water innovation research. Environ. Sci. Policy 2018, 89, 100-108. [CrossRef]

42. Radjou, N.; Prabhu, J.; Ahuja, S. Jugaad Innovation: Think Frugal, Be Flexible, Generate Breakthrough Growth; Jossey-Bass: San Francisco, CA, USA, 2012.

43. Enkel, E.; Gassmann, O.; Chesbrough, H. Open R\&D and open innovation: Exploring the phenomenon. RD Manag. 2009, 39, 311-316. [CrossRef]

44. Production of Industrial Products in 2018, GUS (Statistics Poland). Available online: http://stat.gov.pl/obszary-tematyczne/przemysl-budownictwo-srodki-trwale/przemysl/produkcjawyrobow-przemyslowych-w-2018-roku,3,16.html (accessed on 5 October 2019).

45. Outlays and Results in Industry in 2018, GUS (Statistics Poland). Available online: http://stat.gov.pl/obszary-tematyczne/przemysl-budownictwo-srodki-trwale/przemysl/naklady-iwyniki-przemyslu-w-2018-roku,4,33.html (accessed on 5 September).

46. Statistical Yearbook of Industry-Poland 2018. Available online: http://stat.gov.pl/obszary-tematyczne/ roczniki-statystyczne/roczniki-statystyczne/rocznik-statystyczny-przemyslu-2018,5,12.html (accessed on 6 October 2019).

47. International Statistics Yearbook 2018. Available online: http://stat.gov.pl/obszary-tematyczne/rocznikistatystyczne/roczniki-statystyczne/rocznik-statystyki-miedzynarodowej-2018,10,6.html (accessed on 8 October 2019).

48. Rynek Srebra W 2015 Roku. Available online: http://inwestycje.pl/srebro/Rynek-srebra-w-2015-roku;282762; 0.html (accessed on 9 October 2019).

49. The World Copper Factbook 2016. Available online: http://www.icsg.org/index.php/component/jdownloads/ finish/170/2202 (accessed on 6 September 2019).

50. OECD-Bilateral Trade in Goods by Industry and End-Use (BTDIxE), ISIC Rev.4. Available online: http://stats.oecd.org/\# (accessed on 10 September 2019).

51. Prognozy Na Rynku Stali 2016. Available online: http://www.gb.pl/prognozy-na-rynku-stali-na-2016-pnews431.html (accessed on 15 September 2019).

52. Import Stali Z Chin Szkodzi Unii. Protest Producentów W Brukseli. Available online: http://www.money.pl/gospodarka/unia-europejska/wiadomosci/artykul/import-stali-z-chin-szkodziunii-protest,168,0,2020008.html (accessed on 15 September 2019).

53. Statistical Yearbook of Industry-Poland 2017. Available online: http://stat.gov.pl/obszary-tematyczne/ roczniki-statystyczne/roczniki-statystyczne/rocznik-statystyczny-przemyslu-2017,5,11.html (accessed on 6 October 2019).

54. Statistical Yearbook of Industry-Poland 2016. Available online: http://stat.gov.pl/obszary-tematyczne/ roczniki-statystyczne/roczniki-statystyczne/rocznik-statystyczny-przemyslu-2016,5,10.html (accessed on 6 October 2019).

55. Statistical Yearbook of Industry-Poland 2015. Available online: http://stat.gov.pl/obszary-tematyczne/ roczniki-statystyczne/roczniki-statystyczne/rocznik-statystyczny-przemyslu-2015,5,9.html (accessed on 6 October 2019).

56. Report of the Polish Agency for Enterprise Development, Raport Polskiej Agencji Rozwoju Przedsiębiorczości Monitoring Innowacyjności Polskich Przedsiębiorstw Wyniki II Edycji Badania 2019, Warszawa 2019. Available online: http://www.parp.gov.pl/storage/publications/pdf/Raport-2019---II-edycja-Monitoringinnowacyjnoci-polskich-przedsibiorstw.pdf (accessed on 12 October 2019).

57. Cooper, R.G. The dimensions of industrial new product success and failure. J. Mark. 1979, 43, 93-103. [CrossRef]

58. Hopej-Kamińska, M.; Hopej, M.; Kamiński, R. Prostota Struktury Organizacyjnej A Innowacyjność Organizacji, Doskonalenie Zarzadzania Organizacja. Teoria I Praktyka, Pr. Nauk; Wyższej Szkoły Bank: Gdańsku, Poland, 2015; Volume 40, pp. 13-22.

59. Kamińska, A. (Ed.) Innowacyjność. Uwarunkowania, Strategie, Wyzwania; Placet: Warszawa, Poland, 2014. 
60. Qin, X.; Wang, X.; Xu, Y.; Wei, Y. Exploring Driving Forces of Green Growth: Empirical Analysis on China's Iron and Steel Industry. Sustainability 2019, 11, 1122. [CrossRef]

61. Li, D.; Zheng, M.; Cao, C.; Chen, X.; Ren, S.; Huang, M. The impact of legitimacy pressure and corporate profitability on green innovation: Evidence from China top 100. J. Clean. Prod. 2017, 141, 41-49, ISSN 0959-6526. [CrossRef] 